\title{
Pengaruh pH dan Tegangan Listrik dalam Elektrolisis Limbah Padat Baja (Slag Eaf) Sebagai Upaya Mereduksi Kandungan Logam Fe pada Limbah Padat Industri Galvanis
}

\author{
Abdul Aziz', Wirda Udaibah', Malikhatul Hidayah ${ }^{3}$ \\ 1,2,3Program Studi Kimia Fakultas Sains dan Teknologi Universitas Islam Negeri Walisongo Semarang, \\ Indonesia \\ *Email: aaziz@gmail.com
}

\begin{abstract}
s
Galvanization is a metal coating process that is widely used in industry. The effects of this metal coating process are not entirely beneficial to society. The issue of pollution generated by the metal coating activity becomes very important. The objective of this research is to reduce Fe metal content from solid waste steel using electrolysis process with variation of $\mathrm{pH}$ of electrolyte solution and voltage. This research uses experimental method with test of metal content composition using X-Ray Flouresence, and Fe metal reduction using electrolysis process. This research activity used stainless steel plate as cathode and solid steel waste chunk as anode. Variations of $\mathrm{pH}$ of $\mathrm{FeSO}_{4} \cdot 7 \mathrm{H}_{2} \mathrm{O}$ electrolyte solution used during electrolysis process are $p H=2, p H=2.5, p H=3, p H=3.5$ and $p H=4$. Variation of electric voltage used is 3 volts, 6 volts, 9 volts and 12 volts. The result of purity level analysis of the initial Fe metal at anode was 84,48\%, while after electrolysis process there was an increase of metal purity attached to the cathode of 96,58 \%. The result showed that the effect of $\mathrm{pH}$ variation of the electrolyte solution on the mass produced in the electrolysis process in the $A_{1}, A_{2}, A_{3}, A_{4}$ and $A_{5}$ samples was 0,$09 ; 0,07 ; 0,02 ; 0,02 ;$ and $0,02 \mathrm{~g}$. The greater the concentration of $\mathrm{H}^{+}$of the electrolyte solution the more mass produced. In variable voltage of electricity on samples $A_{11}, A_{21}$, and $A_{31}$ mass produced that is equal to 0,$14 ; 0,13$; and $0,10 \mathrm{~g}$. While the mass of $A_{41}$ sample did not increase in the cathode produced during the electrolysis process. The greater the voltage used in the electrolysis process the greater the mass produced.
\end{abstract}

Kata kunci : Fe metal; solid waste steel; electrolysis

\section{Pendahuluan}

Proses pelapisan logam atau galvanisasi yang dilakukan oleh industri baja dan logam, ternyata tidak sepenuhnya menimbulkan manfaat positif bagi manusia dan lingkungan. Dampak 52 buruk yang ditimbulkan dari proses galvanis oleh pabrik baja di antaranya terbentuk limbah yang berupa gas, cair dan padat. Limbah inilah yang menjadi masalah baru bagi lingkungan, yaitu rusaknya udara, air dan tanah jika limbah tersebut 
terdapat dalam kadar yang tinggi pada saat dibuang ke lingkungan dan dilakukan dalam jangka waktu yang lama (Farid \& Wahid, 2009).

PT. Inti General Jaya Steel adalah salah satu pabrik baja yang ada di Semarang, tepatnya di Desa Jerakah, Tugu, Semarang. Salah satu masalah yang ditimbulkan dari kegiatan operasional pabrik tersebut yaitu terbentuknya gunungan limbah padat di belakang pabrik yang secara langsung berinteraksi ke lingkungan persawahan sekitar pabrik. Menurut Peraturan Pemerintah No. 85 Tahun 1999 tentang Perubahan Atas Peraturan Pemerintah No. 18 Tahun 1999 Tentang Pengelolaan Limbah Bahan Berbahaya Dan Beracun menyatakan dengan tegas bahwa limbah hasil baja masih termasuk dalam limbah Bahan Berbahaya dan Beracun (B3). Akan tetapi, Amerika Serikat dan negara lain (seperti Jepang) mengatakan bahwa limbah slag baja termasuk dalam limbah khusus dan bukan limbah B3 (Gunawan, dkk., 2011). Indonesian Iron and Steel Industri Association (USIA) menyatakan limbah hasil baja merupakan residu prosessing baja hulu.

Logam Fe merupakan salah satu logam berat yang terkandung dalam limbah padat baja yang dalam air minum dapat berupa ion $\mathrm{Fe}^{2+}$ dan ion $\mathrm{Fe}^{3+}$ (Palar, 2008). Semakin banyak indikasi limbah yang mencemari air tanah warga maka semakin banyak pula ion $\mathrm{Fe}^{2+}$ dan ion $\mathrm{Fe}^{3+}$ yang secara tidak langsung dikonsumsi oleh warga. Pencemaran logam berat Fe dalam dosis besar dapat merusak dinding usus hingga kematian. Hal inilah yang menjadi perhatian semua kalangan, khususnya peneliti, yang dituntut untuk dapat mengolah kembali limbah baja agar menjadi solusi permasalahan (Slamet, 2009).

Salah satu solusi untuk mencegah terjadinya pencemaran limbah padat yang dihasilkan dari kegiatan operasional pabrik baja ke lingkungan yaitu dengan cara mengolah kembali atau mendaur ulang tersebut. Salah satu metode yang dapat dilakukan yaitu dengan menggunakan metode elektrolisis. Elektrolisis merupakan salah satu metode alternatif yang dapat digunakan untuk melakukan proses daur ulang limbah padat baja dalam bentuk slag eaf. Proses ini dilakukan dengan menggunakan anoda yang tidak aktif seperti karbon, stainless steel, timbal, titanium. Katoda yang digunakan pada proses elektrolisis merupakan tempat ion logam terlarut dan mengendap berupa bahan logam aluminium, besi dan dilakukan dalam media asam.

Penelitian tentang proses elektrolisis untuk pengambilan logam pernah dilakukan oleh Farid \& Wahid (2009) dari Universitas Diponegoro Semarang. Penelitian ini bertujuan untuk mengurangi kadar seng dari limbah padat industri galvanis. Hasil penelitian tersebut menunjukkan kadar awal seng yang terdapat pada limbah padat adalah 32\%. Kadar seng setelah proses elektrolisis yang terambil dan menempel pada katoda adalah 46\%. Pada penelitian ini juga diketahui bahwa variabel yang paling berpengaruh berturut-turut adalah efek temperature, voltase, dan jarak anodakatoda. Variabel yang lain seperti $\mathrm{pH}$ larutan elektrolit dan arus listrik juga berpengaruh terhadap proses elektrolisis.

Berdasarkan latar belakang di atas, peneliti sangat tertarik untuk melakukan penelitian di bidang tersebut dengan tema pengaruh $\mathrm{pH}$ dan tegangan listrik dalam elektrolisis limbah padat baja (slag eaf) sebagai upaya mereduksi kandungan logam Fe pada limbah padat industri galvanis.

\section{Metode Penelitian}

Alat dan Bahan

Peralatan yang digunakan antara lain: Power supply, Multimeter, Elektroda stainless steel, Statif dan Klem, Kertas saring,Gelas Beker $500 \mathrm{~mL}$, Gelas Beker $250 \mathrm{~mL}$, Gelas ukur $25 \mathrm{~mL}$, Termometer $100^{\circ} \mathrm{C}$ Pipet tetes, $\mathrm{pH}$ meter, Kabel, Kuas dan X-Ray Fuoresence. 
Bahan yang digunakan dalam penelitian ini: bongkahan limbah padat baja dari pabrik baja PT. General Inti Jaya Steel di desa Jerakah kecamatan Tugu Semarang, akuades, lautan

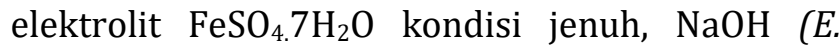
Merck) 0,1 M, $\mathrm{HCl}$ (E. Merck) konsentrasi $1 \mathrm{M}$, $\mathrm{NaOH}$ (E. Merck) konsentrasi $4 \mathrm{M}$, Alkohol $96 \%$, $\mathrm{H}_{2} \mathrm{SO}_{4}$ (E. Merck) konsentrasi1 $\mathrm{M}, \mathrm{K}_{3} \mathrm{Fe}(\mathrm{CN})_{6}$, dan KSCN.

Prosedur Kerja

Preparasi Sampel

\section{Pembersihan Sampel secara Mekanik}

Pembersihan ini bertujuan untuk menghilangkan debu-debu dan pengotor yang menempel pada bongkahan limbah padat baja yang diambil langsung dari lokasi pembuangan limbah pabrik baja menggunakan kuas.

\section{Uji Pendahuluan}

Sampel limbah padat baja dilakukan uji komposisi senyawa menggunakan X-Ray Flouresence untuk mengetahui kandungan logam apa saja yang terdapat dalam sampel.

\section{Pencucian Sampel dengan Asam}

Pencucian dengan asam bertujuan untuk membersihkan permukaan sampel dari oksida atau karat dan sejenisnya secara kimiawi melalui perendaman. Larutan asam ini terbuat dari aquades dan $\mathrm{HCl} 1 \mathrm{M}$ dengan perbandingan 1:1. Selanjutnya dilakukan proses pembilasan menggunakan etanol 96\% untuk menghilangkan sisa reaksi elektroda dengan asam pada saat perendaman sebelumnya, kemudian dikeringkan (Manurung, n.d.).

\section{Proses Elektrolisis}

Limbah padat baja yang telah dibersihkan dari pengotor disiapkan bersama rangkaian alat elektrolisis, yaitu katoda berupa logam stainless steel, anoda berupa limbah padat baja, larutan elektrolit berupa larutan $\mathrm{FeSO}_{4} .7 \mathrm{H}_{2} \mathrm{O}$, power supply dan voltmeter. Susunan rangkaian proses elektrolisis dapat dilihat pada Gambar 1 berikut.

Gambar 1. Skema rangkaian proses elektrolisis

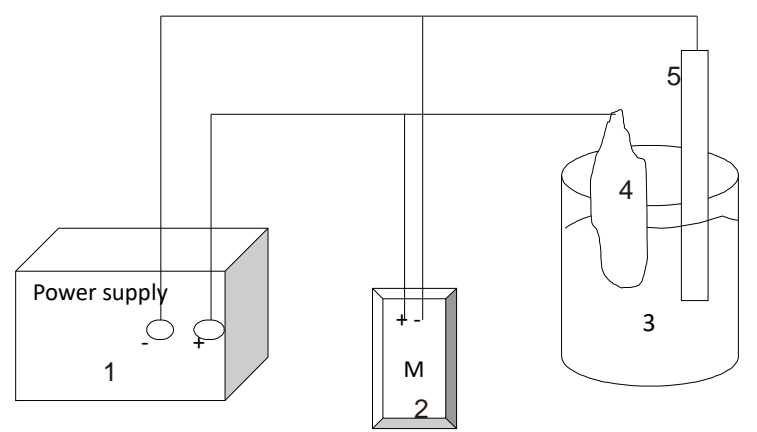

Keterangan:

1) Power supply (sumber daya)

2) Multimeter

3) Larutan elektrolit $\mathrm{FeSO}_{4} .7 \mathrm{H}_{2} \mathrm{O}$

4) Anoda (limbah padat baja)

5) Katoda ( Logam Stainless Steel)

Spesimen dimasukkan dalam larutan dan arus listrik dari power supply dihubungkan sesuai dengan kutub positif dan negatif rangkaian. Arus listrik dari kutub positif dihubungkan ke limbah padat baja sebagai anoda dan arus listrik dari kutub negatif dihubungkan ke logam stainless steel sebagai katoda. Selanjutnya dilakukan proses elektrolisis dengan variabel bebas tegangan listrik. Dilakukan proses elektrolisis dengan optimasi arus listrik arus listrik sebesar 3A, larutan elektrolit $\mathrm{FeSO}_{4} \cdot 7 \mathrm{H}_{2} \mathrm{O}$ dengan $\mathrm{pH}=2$, waktu konstan selama 60 menit dan dalam suhu ruang. Setelah selesai kemudian dimatikan sumber tegangannya dan diangkat spesimen dari bak elektrolisis. Selanjutnya spesimen katoda berupa logam stainless steel yang telah terlapisi logam $\mathrm{Fe}$ yang berasal dari anoda limbah padat baja dibersihkan dengan air dan etanol 96\% untuk membersihkan sisa reaksi yang terjadi selama proses elektrolisis. Selanjutnya dikeringkan. Langkah yang sama juga dilakukan pada kondisi tegangan listrik sebesar 6 Volt, 9 Volt, dan 12 volt dengan arus listrik sebesar $3 \mathrm{~A}$, larutan elektrolit $\mathrm{FeSO}_{4} .7 \mathrm{H}_{2} \mathrm{O}$ dengan $\mathrm{pH}=2$, waktu konstan selama 60 menit dan dalam suhu ruang.

Untuk variabel bebas yang divariasi selanjutnya yaitu $\mathrm{pH}$ larutan elektrolit. Dilakukan proses elektrolisis dengan arus listrik konstan sebesar 3A, tegangan 12 Volt, dan dalam suhu ruang. $\mathrm{pH}$ larutan elektrolit yang divariasi adalah sebesar 2; 2,5; 3; 3,5; dan 4. Untuk 
mengkondisikan $\mathrm{pH}$ pada keadaan asam ditambahkan dengan larutan $\mathrm{H}_{2} \mathrm{SO}_{4} 1 \mathrm{M}$ dan untuk menaikkan nilai $\mathrm{pH}$ ditambahkan dengan larutan $\mathrm{NaOH}$ 0,1 M (Chen, dkk., 2002). Setelah selesai kemudian dimatikan sumber tegangannya dan diangkat spesimen dari bak elektrolisis. Selanjutnya spesimen katoda berupa logam stainless steel yang telah terlapisi logam Fe yang berasal dari anoda limbah padat baja dibersihkan dengan air dan dikeringkan (Manurung, n.d.).

\section{Penimbangan Spesimen}

Setelah proses elektrolisis dilakukan maka dilakukan penimbangan untuk mengetahui berat logam yang tereduksi dan menempel di katoda stainless steel. Kemudian dihitung berat totalnya.

\section{Teknik Analisa Data}

Berat besi yang mengendap di katoda dapat dihitung dengan cara sebagai berikut:

$$
\mathrm{W}=\mathrm{W}_{1}-\mathrm{W}_{0}
$$

Keterangan :

$\mathrm{W}=$ berat total $(\mathrm{gr})$

$\mathrm{W}_{0}=$ berat awal sebelum proses elektrolisis (gr)

$\mathrm{W}_{1}=$ berat akhir sebelum proses elektrolisis (gr)

\section{Hasil Penelitian dan Pembahasan}

\section{Uji X-Ray Flouresence Awal}

Pengujian sampel menggunakan X-Ray Flouresence bertujuan untuk mengetahui komposisi awal logam-logam yang terkandung dalam bongkahan limbah padat baja. Sebelum dilakukan pengujian, sampel bongkahan limbah padat baja terlebih dahulu dihancurkan dan dihaluskan hingga diperoleh butiran halus. Hasil pengujian X-Ray Flouresence awal dapat dilihat pada Tabel 1 berikut ini.
Tabel 1. Komposisi Kimia Limbah Padat Baja sebelum elektrolisis

\begin{tabular}{cc}
\hline Senyawa & Konsentrasi (\%) \\
\hline $\mathrm{Si}$ & 3,8 \\
$\mathrm{P}$ & 0,1 \\
$\mathrm{~K}$ & 0,14 \\
$\mathrm{Ca}$ & 4,76 \\
$\mathrm{~V}$ & 0,03 \\
$\mathrm{Cr}$ & 0,27 \\
$\mathrm{Mn}$ & 2,55 \\
$\mathrm{Fe}$ & 84,48 \\
$\mathrm{Ni}$ & 0,17 \\
$\mathrm{Cu}$ & 0,40 \\
$\mathrm{Zn}$ & 1,59 \\
$\mathrm{Rb}$ & 0,51 \\
$\mathrm{La}$ & 0,1 \\
$\mathrm{Eu}$ & 1,1 \\
\hline
\end{tabular}

Hasil analisa menunjukkan bahwa kandungan logam terbesar yang ada dalam limbah padat baja adalah logam Fe, yaitu sebesar 84,48 \%.

\section{Proses Elektrolisis}

Proses elektrolisis limbah padat baja sebagai upaya mereduksi logam $\mathrm{Fe}$ yang terkandung pada limbah padat baja tersebut menggunakan beberapa komponen selama proses tersebut dilakukan. Rangkaian proses elektrolisis dapat dilihat pada Gambar 2 berikut.

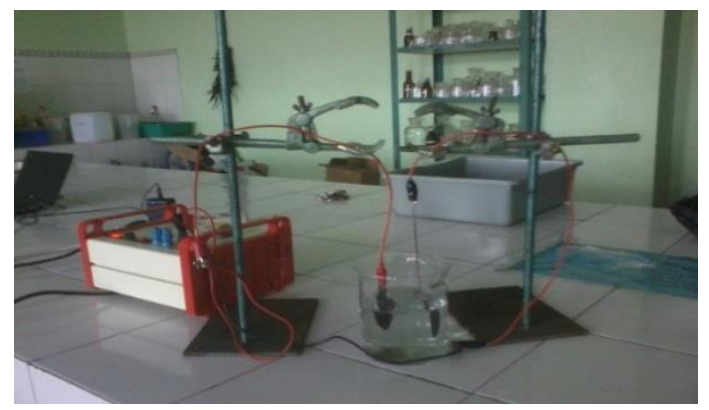

Gambar 2. Rangkaian Proses Elektrolisis

(Sumber: Dokumentasi pribadi, 2015)

Anoda yang digunakan adalah bongkahan limbah padat baja yang selama proses mengalami reaksi oksidasi. Pada proses ini menggunakan juga menggunakan katoda berupa lempengan bahan logam stainless steel yang dipotong dengan ukuran \pm panjang $5 \mathrm{~cm}$ dan lebar $2 \mathrm{~cm}$. Pemilihan katoda dengan bahan stainless steel karena sifat bahan 
tersebut inert yang tidak mudah bereaksi dengan logam lain. Larutan elektrolit yang digunakan selama proses elektrolisis adalah larutan $\mathrm{FeSO}_{4} .7 \mathrm{H}_{2} \mathrm{O}$ dengan kondisi jenuh. Larutan

ion selama proses elektrolisis. Pada proses elektrolisis ini digunakan arus listrik yang berasal dari power supply sebesar 3A. Penggunaan arus listrik sebesar $3 \mathrm{~A}$ bertujuan untuk mendapatkan hasil elektrolisis yang maksimal.

Proses elektrolisis dilakukan dalam dua tahap. Tahap pertama merupakan elektrolisis dengan variasi $\mathrm{pH}$ larutan elektrolit $\mathrm{FeSO}_{4} .7 \mathrm{H}_{2} \mathrm{O}$ mulai dari $\mathrm{pH}=2 ; \mathrm{pH}=2,5 ; \mathrm{pH}=3 ; \mathrm{pH}=3,5$; dan $\mathrm{pH}=4$. Tegangan listrik yang diberikan selama proses elektrolisis adalah sebesar 12 Volt, arus listrik sebesar $3 \mathrm{~A}$. Waktu yang digunakan selama proses elektrolisis yaitu selama 30 menit. Hasil yang diperoleh dapat dilihat pada Tabel 2 .

Tabel 2. Hasil elektrolisis dengan variasi $\mathrm{pH}$ larutan

\begin{tabular}{cccccc}
\hline No & Elektroda & $\mathrm{pH}$ & $\begin{array}{c}\mathrm{W}_{0} \\
(\mathrm{~g})\end{array}$ & $\begin{array}{c}\mathrm{W}_{1} \\
(\mathrm{~g})\end{array}$ & $\begin{array}{c}\Delta \mathrm{W} \\
(\mathrm{g})\end{array}$ \\
\hline \multirow{2}{*}{ 1. } & $\mathrm{A}_{1}$ & & 5,04 & 5,15 & $+0,09$ \\
& & 2 & & & \\
& $\mathrm{~B}_{1}$ & & 37,48 & 37,29 & $-0,19$ \\
\hline \multirow{2}{*}{2.} & $\mathrm{~A}_{2}$ & & 5,15 & 5,22 & $+0,07$ \\
& & 2,5 & & & \\
& $\mathrm{~B}_{2}$ & & 32,48 & 32,37 & $-0,11$ \\
\hline \multirow{2}{*}{ No } & Elektroda & $\mathrm{pH}$ & $\mathrm{W}_{0}$ & $\mathrm{~W}_{1}$ & $\Delta \mathrm{W}$ \\
& & & $(\mathrm{g})$ & $(\mathrm{g})$ & $(\mathrm{g})$ \\
\hline 3. & $\mathrm{~A}_{3}$ & & 4,39 & 4,41 & $+0,02$ \\
& & 3 & & & \\
& $\mathrm{~B}_{3}$ & & 35,30 & 35,02 & $-0,28$ \\
4. & $\mathrm{~A}_{4}$ & & 4,73 & 4,75 & $+0,02$ \\
& & 3,5 & & & \\
& $\mathrm{~B}_{4}$ & & 27,14 & 26,88 & $-0,26$ \\
& $\mathrm{~A}_{5}$ & & 4,73 & 4,75 & $+0,02$ \\
5. & & 4 & & & \\
& $\mathrm{~B}_{5}$ & & 19,65 & 19,37 & $-0,28$ \\
\hline
\end{tabular}

Keterangan:

$\mathrm{A}=$ elektroda katoda

$\mathrm{B}$ = elektroda anoda

$\mathrm{W}_{0}=$ massa elektroda sebelum proses elektrolisis

$\mathrm{W}_{1}=$ massa elektroda setelah proses elektrolisis

56
$\Delta \mathrm{W}=$ berat akhir elektroda

$+\quad=$ massa elektroda bertambah

- $\quad$ = massa elektroda berkurang

Berdasarkan Tabel 2 tersebut, dapat diketahui hubungan antara variabel $\mathrm{pH}$ larutan elektrolit dan massa akhir hasil proses elektrolisis sebagaimana disajikan dalam Gambar 3 berikut.

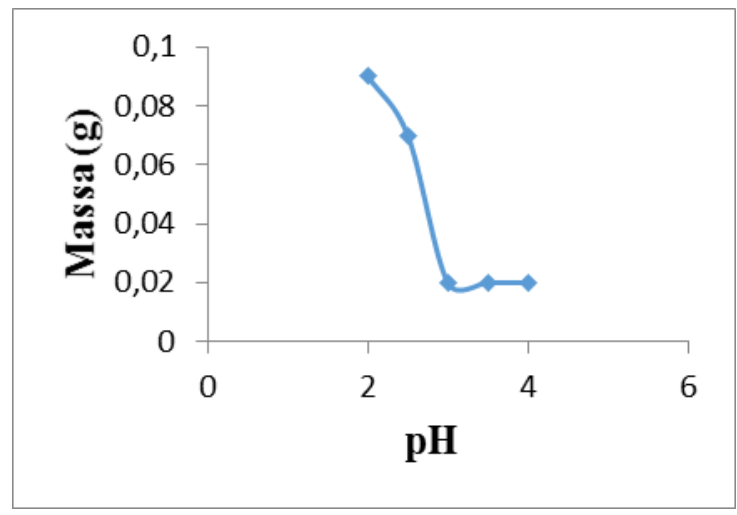

Gambar 3. Grafik hubungan pH larutan elektrolit dengan massa

Berdasarkan Tabel 3 di atas, dapat diketahui pula bahwa dari kelima sampel yang digunakan, semuanya mengalami penambahan massa pada masing-masing spesimen katoda yang berupa lempengan logam stainless steel. Hasil terbaik adalah pada spesimen sampel $A_{1}$ dengan berat spesimen katoda bertambah sebesar 0,09 $\mathrm{g}$.

Selisih yang terjadi antara massa katoda dan anoda setelah proses elektrolisis disebabkan karena penggunaan larutan elektrolit $\mathrm{FeSO}_{4} \cdot 7 \mathrm{H}_{2} \mathrm{O}$. Larutan ini berpotensi menghasilkan deposit atau endapan logam berwarna abu-abu halus yang menempel pada katoda (Izaki, 2010). Logam yang menempel pada katoda bersifat lebih rapuh sehingga mudah patah dan jatuh ke dalam larutan elektrolit. Hal inilah yang mempengaruhi berat akhir logam yang menempel pada katoda. Pembentukan deposit pada katoda dipengaruhi pula oleh nilai keasaman larutan elektrolit. Semakin besar nilai keasaman larutan elektrolit (variasi nilai $\mathrm{pH}$ ) maka akan mengakibatkan peningkatan pembentukan jumlah elektron yang dihasilkan selama proses elektrolisis, sehingga deposit yang terbentuk akan semakin besar.

Tahap kedua pada proses elektrolisis limbah padat baja yaitu dengan menggunakan 
variasi tegangan listrik yang berbeda selama proses elektrolisis. Variasi tegangan listrik yang digunakan yaitu sebesar 3 Volt, 6 Volt, 9 Volt, dan 12 Volt. pH larutan elektrolit $\mathrm{FeSO}_{4} \cdot 7 \mathrm{H}_{2} \mathrm{O}$ yang digunakan adalah $\mathrm{pH}=2$, dan arus listrik sebesar 3 A (berasal dari power supply) serta waktu proses elektrolisis dilakukan selama 30 menit. Hasil yang diperoleh dapat dilihat pada Tabel 3 berikut.

Tabel 3. Hasil Elektrolisis dengan Variasi Tegangan Listrik

\begin{tabular}{|c|c|c|c|c|}
\hline \multicolumn{2}{|c|}{ No Elektroda } & $\begin{array}{l}W_{0} \\
(\mathrm{~g})\end{array}$ & $\begin{array}{l}W_{1} \\
(g)\end{array}$ & $\begin{array}{l}\text { W } \\
\text { (g) }\end{array}$ \\
\hline \multirow{2}{*}{1.} & $A_{11}$ & 4,22 & 4,36 & $+0,14$ \\
\hline & $\mathrm{B}_{11}$ & 15,11 & 14,74 & $-0,37$ \\
\hline \multirow{2}{*}{2.} & $\mathrm{~A}_{21}$ & 4,17 & 4,30 & $+0,13$ \\
\hline & $\mathrm{B}_{21}$ & 12,63 & 12,44 & $-0,19$ \\
\hline \multirow{2}{*}{3.} & $A_{31}$ & 4,19 & 4,29 & $+0,10$ \\
\hline & $\mathrm{B}_{31}$ & 28,80 & 28,20 & $-0,6$ \\
\hline \multirow{2}{*}{4.} & $\mathrm{~A}_{41}$ & 3,80 & 3,80 & +0 \\
\hline & $\mathrm{B}_{41}$ & 9,32 & 9,32 & -0 \\
\hline
\end{tabular}

\section{Keterangan: \\ $\mathrm{W}_{0} \quad=$ massa elektroda sebelum proses elektrolisis \\ $\mathrm{W}_{1}=$ massa elektroda sesudah proses elektrolisis \\ $\Delta \mathrm{W}=$ berat akhir elektroda \\ $+\quad=$ massa elektroda bertambah \\ - $\quad=$ massa elektroda berkurang}

Berdasarkan Tabel 3 di atas, dapat diketahui bahwa terdapat 3 sampel yang mengalami perubahan kenaikan berat spesimen pada elektroda negatif, yaitu $A_{11} A_{21}$ dan $A_{31}$ yaitu sebesar 0,$14 ; 0,13$; dan 0,10 g. Sedangkan sampel dengan kode $\mathrm{A}_{41}$ tidak mengalami perubahan berat pada spesimen elektroda atau tetap. Selama proses elektrolisis, terjadi kenaikan suhu pada larutan elektrolit yang digunakan pada masingmasing sampel. Hal ini menunjukkan bahwa tegangan listrik sangat berpengaruh dalam proses elektrolisis. Semakin besar tegangan listrik yang diberikan maka semakin besar logam yang terambil dan menempel pada katoda.

Hubungan antara tegangan listrik dengan besar massa berdasarkan hasil yang diperoleh pada tahap kedua ini dapat dilihat pada Gambar 4 berikut.

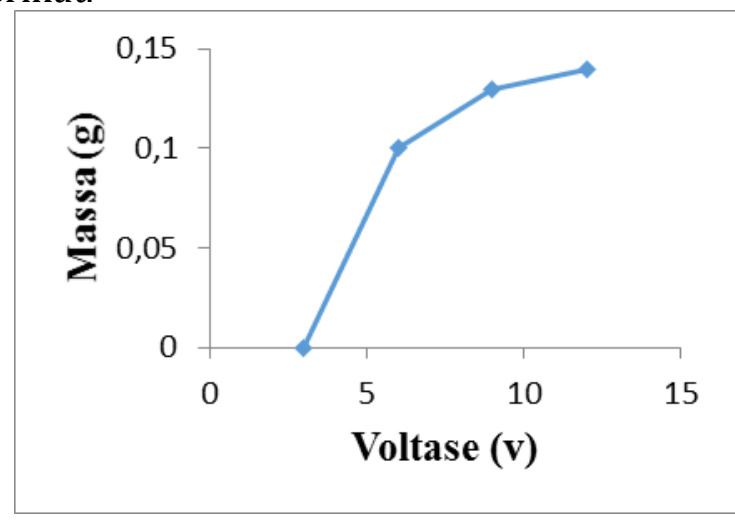

Gambar 4. Grafik hubungan tegangan listrik dengan massa

\section{Uji X-Ray Flouresence Akhir}

Setelah melakukan proses elektrolisis dengan variasi $\mathrm{pH}$ larutan dan besar tegangan listrik, didapatkan hasil padatan yang menempel pada katoda seperti pada Gambar 4 berikut.

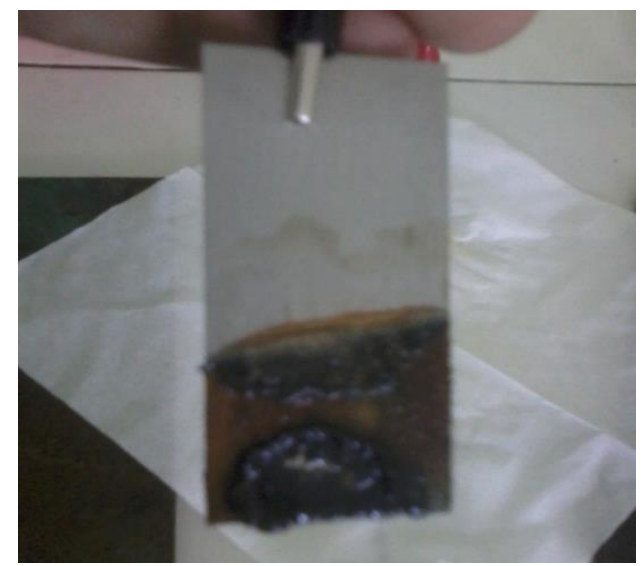

Gambar 5. Hasil Padatan Proses Elektrolisis

Hasil elektrolisis yang berupa padatan yang menempel pada katoda kemudian diambil dengan cara dikerok. Serbuk logam berwarna cokelat keemasan yang diperoleh diuji menggunakan X-Ray Flouresence. Pengujian ini bertujuan untuk mengetahui komposisi kandungan kimia pada sampel setelah dilakukan elektrolisis, sehingga dapat dibandingkan dengan 
hasil sampel sebelum dielektrolisis. Hasil pengujian $X$-Ray Flouresence akhir disajikan pada Tabel 4 berikut.

Tabel 4. Komposisi Kimia Limbah Padat Baja setelah elektrolisis

\begin{tabular}{cc}
\hline Senyawa & Konsentrasi (\%) \\
\hline $\mathrm{P}$ & 0,1 \\
$\mathrm{Ca}$ & 0,21 \\
$\mathrm{Cr}$ & 0,11 \\
$\mathrm{Mn}$ & 0,15 \\
$\mathrm{Fe}$ & 96,58 \\
$\mathrm{Ni}$ & 0,12 \\
$\mathrm{Cu}$ & 0,14 \\
$\mathrm{Zn}$ & 0,14 \\
$\mathrm{Rb}$ & 0,67 \\
$\mathrm{La}$ & 0,03 \\
$\mathrm{Mo}$ & 1,6 \\
$\mathrm{Re}$ & 0,2 \\
\hline
\end{tabular}

Tabel 4 di atas menunjukkan bahwa hasil elektrolisis yang menempel pada katoda mengandung logam Fe sebesar 96,58 \%, Rb 0,67 $\%$, Mo 1,6 \%, Cu 0,14 \%, Zn 0,14 \%, Ca 0,21\%, Mn $0,15 \%$, Cr 0,11 \%, Ni 0,12\%, P 0,1\%, Re 0,2\% dan La 0,03\%.Hasil tersebut menunjukkan bahwa tingkat kemurnian logam $\mathrm{Fe}$ yang terendapkan lebih tinggi daripada sebelum dimurnikan dengan metode elektrolisis. Selisih tingkat kemurnian logam $\mathrm{Fe}$ pada bongkahan limbah padat baja sebelum dan sesudah dilakukan proses elektrolisis adalah sebesar $12,10 \%$.

Berdasarkan hasil penelitian yang dilakukan, dapat diketahui bahwa logam Fe yang terkandung dalam bongkahan limbah padat baja dapat direduksi menggunakan metode elektrolisis. Oleh karena itu, elektrolisis dapat dijadikan sebagai salah satu alternatif metode dalam pemurnian logam.

\section{Kesimpulan}

Berdasarkan penelitian yang telah dilakukan, maka dapat diambil kesimpulan sebagai berikut.

1. Proses elektrolisis dilakukan dengan menggunakan katoda lempengan logam stainless steel, anoda berupa bongkahan limbah padat baja dan larutan elektrolit $\mathrm{FeSO}_{4} \cdot 7 \mathrm{H}_{2} \mathrm{O}$. Arus listrik yang digunakan sebesar $3 \mathrm{~A}$ dan waktu yang digunakan pada proses elektrolisis selama 30 menit. Kemurnian logam Fe pada limbah padat baja sebelum dilakukan proses elektrolisis adalah sebesar 84,84\%. Kemudian setelah dilakukan pemurnian dengan elektrolisis logam Fe yang menempel pada katoda meningkat menjadi 96, $58 \%$.

2. Variabel pH larutan elektrolit berpengaruh terhadap massa yang dihasilkan selama proses elektrolisis. Deposit massa maksimal terjadi pada kondisi larutan elektrolit $\mathrm{pH} 2$ dengan terjadi penambahan berat pada katoda sebesar $0,09 \mathrm{~g}$. Semakin kecil $\mathrm{pH}$ keasaman larutan elektrolit maka semakin besar massa yang dihasilkan.

3. Variabel tegangan listrik berpengaruh terhadap massa yang dihasilkan selama proses elektrolisis. Hasil maksimal ditunjukkan pada kondisi tegangan 12 Volt dengan massa logam yang terambil sebesar 0,14g. Hal ini menunjukkan bahwa semakin tinggi tegangan yang digunakan selama proses elektrolisis maka massa yang dihasilkan akan ikut meningkat.

\section{Daftar Pustaka}

Chang, Raymond. 2005. Kimia Dasar Jilid 2. Jakarta: Erlangga.

Chen, Xueming, dkk. 2002. Investigation On The Electrolysis Voltage of Electrocoagulation. Chemical Engineering Science.

Farid, Ahmad dan Nur Wahid. 2009. Proses Elektrolisis untuk Pengambilan Seng dari Limbah Padat Industri Galvanis. Semarang: UNDIP.

Gunawan, G., dkk. 2011. Pemanfaatan Slag Baja untuk Teknologi Jalan Yang Ramah Lingkungan. Bandung: Kementerian Pekerjaan Umum.

58 
Izaki, Masanobu. 2010. Modern Elektroplating Fifth Edition.

Manurung, Charles. (n.d.). Pengaruh Kuat Arus Terhadap Ketebalan Lapisan dan Laju Korosi (MPY) Hasil Elektroplating Baja Karbon Rendah dengan Pelapis Nikel. Medan.

Palar, Heryando. (2008). Pencemaran dan Toksikologi Logam Berat. Jakarta: Rineka Cipta.

Slamet, Juli Soemirat. (2009). Kesehatan Lingkungan, Yogyakarta: Gadjah Mada University Press. 